\title{
On Nik. Fabrikant and His Article
}

\author{
Serhiy Bilenky \\ University of Toronto
}

$\mathrm{N}$ ik[olai] Fabrikant was the pseudonym of Ivan Krevets'kyi, a wellknown Ukrainian intellectual who functioned as a historian, a bibliographer, and a civic activist in Austrian-ruled Galicia. In 1905, Krevets'kyi (under his pseudonym) published in Russian his arguably most famous polemical piece on the Russian censorship of Ukrainian literature in the Russian liberal periodical Russkaia mysl' (Russian Thought), one of the most widely circulating Moscow journals (with around 14,000 subscribers at its peak). Krevets'kyi's "Kratkii ocherk iz istorii otnoshenii russkikh tsenzurnykh zakonov k ukrainskoi literature" ("A Brief Outline of the History of the Treatment of Ukrainian Literature by the Russian Censorship Laws") was not an original publication but rather a revision of the author's Ukrainian-language article "Ne bylo, net i byt' ne mozhet!" ("There Has Not Been, Is Not, and Cannot Be!") ${ }^{1}$ published in 1904 in the prime Ukrainian journal Literaturno-naukovyi visnyk (Literary Scientific Herald), a literary and scholarly periodical founded by historian Mykhailo Hrushevs'kyi with the participation of such luminaries as Ivan Franko and Volodymyr Hnatiuk.

Krevets'kyi was born on 14 October, 1883, in the village of Ivanivka (which today belongs to the Zhydachiv district of Lviv oblast) (Steblii 3-5; Fedunyshyn). Born in a teacher's family, he went on to study in the prestigious Ukrainian academic gymnasium in Lviv, and in 1907 he graduated from Lviv University where he studied history under Hrushevs'kyi, with whom the young graduate relocated for a while in Kyiv. Krevets'kyi helped his teacher edit the journal Literaturno-naukovyi visnyk, now transferred to Kyiv. Even before his graduation he became a member of the Shevchenko Scientific Society (NTSh) (from 1907 he was a full member); he also directed its library (1905-14 and 1921-37). Under Krevets'kyi's tenure, the society's library held the largest collection of Ukrainian books, journals, and manuscripts, as well as writings on Ukraine in any language; the library contained up to 300,000 volumes of prints and manuscripts by the late 1930s. From 1909 Krevets'kyi served as secretary of the historical-

\footnotetext{
1 The title of the article is in Russian because it contains an allusion to the infamous quote from the Valuev Directive of 1863: "No distinct Little Russian language has ever been, is, and cannot be" ("nikakogo osobennogo malorossiiskogo iazyka ne bylo, net $i$ byt' ne mozhet").
} 
philosophical section of the society. At its meetings the young historian regularly reported about his own research and gave assessments of the contributions of the society's other members. He was also a deputy head of the bibliographic commission of NTSh. Throughout his prolific career Krevets'kyi edited several academic and popular periodicals, among them the historical monthly Stara Ukraina (Old Ukraine, 1924-25), the pedagogical journal Nasha shkola (Our School, 1909-12), and Respublyka, a press organ of the Western Ukrainian National Republic in Stanislaviv (1919). From 1919 to 1921 Krevets'kyi worked in Kyiv at the library of the Ukrainian Academy of Sciences. In the 1920s he conducted a seminar on Ukrainian military history at the Ukrainian Underground University in Lviv. He died on 27 June, 1940, in the town of Rozdil, Zhydachiv (today Mykolaiv) district of Lviv oblast.

Krevets'kyi published some forty articles on Galician history, most of which appeared in the main scholarly organ of the Shevchenko Scientific Society Zapysky NTSh (The Notes of the Shevchenko Scientific Society). Many of these articles dealt with the revolution in eastern Galicia in 1848, particularly with the organization of Ukrainian armed units, the failed attempts to divide the province between Poles and Ukrainians, and the Austrian election in 1848. His major work on Galician history was the monograph Ahrarni straiky i boikoty u Skhidnii Halychyni v 1848-1849 rr.: Do istorii borot'by za suspil'no-ekonomichne vyzvolennia ukrains'kykh mas u Skhidnii Halychyni (Agrarian Strikes and Boycotts in Eastern Galicia in 18481849: Toward the History of the Struggle for the Economic Liberation of the Ukrainian Masses in Eastern Galicia, 1906). His other areas of expertise included medieval Kyivan Rus' (he studied ancient burials in such Kyiv monuments as St. Sophia, the Tithe Church, and the Monastery of Caves), the Dnieper Ukraine history in the seventeenth and eighteenth centuries, and Ukrainian book printing, press, historiography, and memoirs.

While still a student at Lviv University, Krevets'kyi wrote his most famous polemical piece: a history of Russian censorship of Ukrainian cultural products ranging from book publishing to theatre performances. Most likely commissioned by his mentor Hrushevs'kyi, this ambitious article appeared in the leading Ukrainian journal of the time, Literaturno-naukovyi visnyk. The young author, still a student, collaborated with this journal and continued to do so in later years. The journal was a monthly publication that appeared in Lviv, 1898-1906 and 1922-32; in Kyiv, 1907-14 and 1917-19; and in Regensburg and Munich, 1948-49 (two issues). Each period was marked by particular circumstances and leading authors. If the first Lviv and Kyiv periods were defined by Hrushevs'kyi and his liberal and populist colleagues, the interwar Lviv publication under the editorship of Dmytro Dontsov became a mouthpiece of more radical nationalism. Krevets'kyi was an author or translator of many bibliographical articles and short reports, 
primarily before World War I. Among his major publications, along with the piece on Russian censorship, at least two should be mentioned here: "Kyivs'ke istorychne tovarystvo Nestora-Litopystsia" ("Kyiv Historical Society Named After Nestor the Chronicler") and "Sprava podilu Halychyny v rr. 1846-1850: Z istorii borot'by halyts'kykh ukraintsiv za natsional'noterytoriial'nu avtonomiiu" ("On the Division of Galicia in 1846-1850: From the History of Struggle of Galician Ukrainians for Their National-Territorial Autonomy").

The Russian translation of Krevets'kyi's article “There Has Not Been, Is Not, and Cannot Be!" appeared under the pseudonym Nik. Fabrikant in the Russian liberal journal Russkaia mysl'.2 It is the translation of this Russianlanguage text that is being published in the current volume of East/West: Journal of Ukrainian Studies. The Russkaia mysl'journal was founded in 1880 by publisher and translator Vukol M. Lavrov (1852-1912), a zealous propagator of the new Polish literature (he translated the works of Henryk Sienkiewicz, Władysław Reymont, and Eliza Orzeszkowa). Under the editorship of Lavrov the journal adhered to the position of moderate constitutionalism, which prepared the ground for the creation of the Constitutional Democratic Party (informally known as the Kadets) in 1905. At various times the journal published contributions by several prominent Ukrainian intellectuals, among them Mykola Kostomarov, Oleksandra Iefymenko, and Maksym Kovalevs'kyi. After 1905 Russkaia mysl' became an organ of the right faction of the Kadets, and in 1906 its founding editor Lavrov left the journal. Apparently it was still under the old editorial board that Krevets'kyi published his seminal article.

Compared to its original, the version published in Russkaia Mysl' is somewhat milder in assessing the overall Russian politics vis-à-vis Ukraine. Whereas Krevets'kyi started out by bluntly accusing Russia of "destroying" Ukraine's "political independence," his alter ego Fabrikant began with a narrower subject-the "draconian cruelty" of Russian censorship. In general, however, the two texts are very similar, so much so that one can speak about the Russian translation from the Ukrainian original, not the revision, as stated in a footnote to the Russian version. Whether it was a revision or translation, the omission in the Russian text of a number of quotations, examples, and personal characteristics is noticeable. For example, while Krevets'kyi called Mykhailo Iuzefovych, a notorious persecutor of the Sts. Cyril and Methodius Brotherhood, a "traitor,"

\footnotetext{
2 A comment about the article included in the publication noted that this was a revision of a piece that appeared in Literaturno-naukovyi visnyk. This was not the only Russian version of Krevets'kyi's seminal article. Another Russian translation of his article, this time under his real name, appeared in the Kharkiv liberal journal Nakanune (On the Eve), no. 86, 1906 (Maliutina).
} 
Fabrikant simply grouped him with other Russian officials responsible for shutting down Ukrainian activities in 1876. Fabrikant excluded lengthy quotations from Volodomyr Barvyns'kyi's assessment of Russification and its repercussions for Galician Ukrainians. Equally missing from the Russian version was a long quote from Ivan Puliui's 1904 petition concerning the ban on Ukrainian translations of the Bible. We also will not find Mykhailo Drahomanov's words from his seminal report (La Littérature oukrainienne proscrite par le gouvernement russe. Rapport présenté au congrès littéraire de Paris, 1878) on Ukrainian literary works banned by the Russian government. The most striking difference, however, concerned the ending of Fabrikant's article: it looks as if the author interrupted his writing in the middle of an argument enumerating Galician periodicals that were smuggled into Russian Ukraine. A few final pages of Krevets'kyi's article were completely omitted by Fabrikant (or by his Russian publishers). In those omitted pages one could learn about the most recent censorial attacks on Ukrainian literature (cases coming from the early twentieth century). Perhaps the Russian editors found some statements in the Ukrainian original too risky for a Russian periodical. For example, Krevets'kyi wrote: "[Now] anyone can see the barbarity of the Russian government that very much wants to consider itself cultivated: it even has got the ministry of 'education'!" ("Ne bylo, net i byt' ne mozhet," 14-15, translation is mine-S.B.) Then Krevets'kyi appealed to the world's public opinion (including "American Ruthenians"), as a way to "force [the] tsarist government" to lift all the bans on Ukrainian literature. Another way to circumvent such censure was to take advantage of Austrian Galician presses, so that the Russian government would find it futile to ban Ukrainian literature in Russian Ukraine. In the end Krevets'kyi preached a radical intellectual separation of Ukrainians from Russia, self-reliance instead of loyalty. Clearly the Russian public, even its most liberal circles, was not ready to tolerate such a radically separatist message. For all that, the publication of Fabrikant's / Krevets'kyi's piece in a popular Moscow journal was a remarkable sign that Russian liberals felt sympathy for their oppressed Ukrainian colleagues, an example of intellectual honesty and moral integrity for all times.

\section{Works Cited}

Fabrikant, Nik. "Kratkii ocherk iz istorii otnoshenii russkikh tsenzurnykh zakonov k ukrainskoi literature." Russkaia mysl', vol. III, 1905, pp. 127-46.

Fedunyshyn, Liubomyra. "Polikul'turotvorcha diial'nist' Ivana Krevets'koho." Visnyk Derzhavnoi akademii kerivnykh kadriv kul'tury, no. 3, 2009, pp. 122-26.

Krevets'kyi, Ivan. "Kyivs'ke istorychne tovarystvo Nestora-Litopystsia." Literaturnonaukovyi visnyk, vol. XXVIII, Oct., Nov., Dec., 1904, pp. 65-72. 
---. “'Ne bylo, net i byt' ne mozhet'." Literaturno-naukovyi visnyk, vol. XXVI, April, May, June, 1904, pp. 129-58; vol. XXVII, July, Aug., Sept., 1904, pp. 1-18.

---. "Sprava podilu Halychyny v rr. 1846-1850: Z istorii borot'by halyts'kykh ukraintsiv za natsional'no-terytoriial'nu avtonomiiu." Zapysky NTSh, vol. XCIII, 1910, pp. 54-69; vol. XCVII, pp. 105-54.

Maliutina, 0. S. "Kharkivs'ki kadets'ki vydannia periodu pershoi rosiis'koi revoliutsii pro natsional'ne pytannia." Visnyk NTU 'KhPI', no. 65 (971), 2012, pp. 36-41.

Steblii, Fedir. Ivan Krevets'kyi-istoryk-derzhavnyk. Instytut ukrainoznavstva NAN Ukrainy, 2003. 